\title{
Screening of Bovine Mastitis in Lactating Dairy Cows in and around Debra Tsige Town, North Ethiopia
}

\author{
Debela Abdeta $^{1 *}$ and Desalegn Shiferaw ${ }^{2}$ \\ ${ }^{1}$ Wollega University School of veterinary medicine, Ethiopia \\ ${ }^{2}$ Debra Tsige Town Veterinary Clinics, Ethiopia \\ *Corresponding author: Debela Abdeta, Wollega University School of veterinary medicine, Ethiopia
}

\section{ARTICLE INFO}

Received: 慧 March 14, 2020

Published: 蔧 June 11, 2020

Citation: Debela A, Desalegn S. Screening of Bovine Mastitis in Lactating Dairy Cows in and around Debra Tsige Town, North Ethiopia. Biomed J Sci \& Tech Res 28(2)2020. BJSTR. MS.ID.004619.

Keywords: Clinical mastitis; CMT; Debre Tsige; Prevalence; Subclinical Mastitis
ABSTRACT

Mastitis an inflammation of the mammary gland caused by pathogenic microorganism, occurs in all mammalian species, particularly in dairy cattle. A cross sectional study design was conducted from June 2017 to December 2017 to screening bovine mastitis in randomly selected dairy farms in and around Debre Tsige. 384(119 cross, 214Exotic, 51 local breed) of lactating cows were included in the study. Prevalence of the clinical mastitis was determined through examination of abnormalities of milk and udder. The overall prevalence of clinical mastitis was $6.5 \%$ and $1.82 \%$ at cow and quarter level, respectively. Individual quarter milk samples from those which were normal in clinical mastitis were tested by California Mastitis Test (CMT) to diagnose sub - clinical mastitis. Of the 1536 quarters examined, prevalence of clinical mastitis, sub clinical mastitis and blind quarters (nonfunctional teats) were found to be $6.5 \%$, $30.2 \%$ and $0.97 \%$, respectively. On cow basis, out of 384 lactating cows, $143(36.7 \%)$ cows had abnormalities in their udder, teats, and milk as evidence of clinical mastitis. The prevalence of mastitis at cow level was higher in exotic breeds101 (26.30\%) and in cows those which were found in late lactation stage63 (16.40\%), which was found to be statistically significant $(\mathrm{P}<0.05)$. The present study revealed that parity number was also found to have significant association with the prevalence of mastitis $(\mathrm{P}<0.05)$. In the present study, there was high prevalence of sub clinical mastitis that result losing of milk production and cause economic lose to the dairy farm. In view of this, the routine test of dairy cows, and preventive and control measures are recommended to reduce the prevalence of clinical and sub clinical mastitis in dairy farms in and around Debre Tsige.

\section{Introduction}

The majority of the third world countries are located in tropic and livestock production is very important to their economy. Dairying is a component of livestock production is an important economic activity in sub Saharan Africa. Ethiopia is the nations that possess the largest livestock population among African continent with an estimated 30-33 million cattle [1,2]. Moreover, the quality and quantity of milk in the country deteriorates because of various causes. Mastitis is an inflammation of the parenchyma of mammary gland and commonly associated with intra mammary bacterial infection. It is considered as one of the most important disease among diseases of the dairy animals; it is characterized by physical, chemical, bacteriological changes in milk, and pathological changes in glandular tissues [3]. Bovine mastitis (mast = breast; itis = inflammation), a major disease affecting dairy cattle worldwide, results from the inflammation of the mammary gland. The severity of the inflammation can be classified into sub-clinical, clinical, and chronic forms, and its degree is dependent on the nature of the causative pathogen and on the age, breed, immunological health, and lactation state of the animal. Sub-clinical mastitis is difficult to detect due to the absence of any visible indications, and it has major cost implications chronic mastitis is a rare form of the disease but results in persistent inflammation of the mammary gland currently, milk quality payments are based on somatic cell counts (SCCs), and elevated levels result in reduced payments. This, in addition to reduction in milk volume and treatment costs, significantly affects farm incomes [4]. 
Mastitis is a difficult problem to comprehend because, it is a disease caused by many factors, both in large and in small-scale herds. Micro-organisms are responsible for the infection, but for them to enter the mammary gland and establish themselves to the point that they cause an infection, a multitude of factors may be involved. There are many factors acting simultaneously, and the disease generally involves interplay between management practice and infectious agents but with other factors, such as genetics, udder shape or climate $[5,6]$. The occurrence of disease is an outcome of interplay between three major factors: infectious agents, host, and environmental factors [7]. Mastitis is a global problem as it adversely affects animal health, quality of milk and the economics of milk production, affecting every country, including developed ones and causes huge financial losses [8]. Mastitis could be classified as clinical or sub clinical. Clinical mastitis refers to inflammation of mammary gland with grossly visible changes on the udder and milk. It is characterized by abnormalities such as discoloration of milk, redness, increased temperature, pain, and disturbance of function of the udder [9]. Sub clinical mastitis on the other hand refers to inflammation of mammary gland in the absence of visible changes in the udder but presence of pathogenic organisms in the milk and can only be diagnosed with indirect screening tests or laboratory culturing [10].

Due to the heavy financial implications involved and inevitable existence of latent infection, it is obvious that mastitis is an important factor limiting dairy production. The disease is worth studying due to the financial loss involved as a result of reduced milk yield, discarded milk following antibiotic therapy, easily culling of cows, veterinary costs, drug costs, increased labor, death of per acute cases and replacement costs. Additional economic incentives to control mastitis include consumers' acceptance and product shelf- life factors. Although all of these factors result in considerable economic loss, decreased milk production is the single most important economic consideration and this requires the development of methodologies of control program under prevailing husbandry system [11]. The limited studies showed that bovine mastitis as a disease has received little attention in Ethiopia so far, especially the sub clinical form. There is no study conducted still know in Derbe Tsige areas. Therefore, the present study will have the following main objective:

a) To screening bovine mastitis in selected dairy farms in and around Debre Tsige

b) To assess the major risk factors associated with the occurrence of the bovine mastitis in the selected area in and around Debre Tsige.

\section{Materials and Methods}

\section{Study Area}

This study was conducted in and around DebreTsige town in North Showa zone of Oromia, Ethiopia. DebreTsige town is located $9048 \mathrm{~N}$ and $38 \mathrm{o} 44 \mathrm{E}$ at about $89 \mathrm{~km}$ north of Addis Ababa. The altitude of the district is between $1500-2700 \mathrm{~m}$ a.s.l, its minimum and maximum temperature varies from $19 \mathrm{oC}$ to $23 \mathrm{oC}$. It gets bimodal rain fall that ranges from $800-1200 \mathrm{~mm}$ and the predominant soil type are black soil (56\%) and red soil (38\%). Two agro ecologies are found in the area and mixed agricultural activities are performed. There are about 81,796 head of cattle, 8480 goats, 24923 sheep, 10200 equines, and 80,305 poultry in the districts of Debre Libanosworeda where the town is DebreTsige. All of these livestock species are reared mainly by smallholder farmers under intensive, semi intensive, and extensive production system. The district is divided into 11 administrative PAs and 15,000 liters of milk is collected from DebreTsige town (DWLFO,2014).

\section{Study Population}

The study populations were selected from different farms which were large, medium, and small-scale dairy farms. The study population from each scale dairy farms was divided by their proportion. The study populations in selected farms were selected by simple random sampling technique; and all was lactating cows. Lactating dairy cattle that were selected in this study was indigenous Zebu breed, cross (holestain and Zebu) breed and exotic breeds found in different scale dairy farms. Individual animal was selected randomly and tested for mastitis using CMT and clinical examinations. The farms that were included in this study were market-oriented small holder, medium - sized dairy farms and large dairy farms. Classification was by (Lemma et al., 2001) by considering as smallholder ( $<5$ heads of dairy cow), medium sized (6-50 heads of dairy cow) and large ( $>50$ heads of dairy cow).

\section{Study design}

A cross sectional study was conducted from June 2017 to December 2017 on milking dairy cows to determine the prevalence of clinical and subclinical mastitis in different farms in and around Debre Tsige town.

Sample Size Determinations

$$
\begin{aligned}
\mathrm{n} & =1.962 \mathrm{p} \exp (1-\text { pexp }) / \mathrm{d}^{2} \\
& =1.9620 .5(1-0.5) / 0.052 \\
& =384
\end{aligned}
$$

Where $n=$ sample size required

1.96=the value of $\mathrm{Z}$ at $95 \%$ confidence interval

$\mathrm{P} \exp =$ expected prevalence

$\mathrm{d}=$ desired absolute precision

An expected prevalence of the selected area is 0.5 so; this was used to increase the degree of precision and considering a $5 \%$ absolute precision and at 95\% confidence level was give us 384 sample sizes [12]. 


\section{Study Methodology}

A total of 384 lactating cows; 214 exotic, 119 cross and51 local breeds were sampled from the randomly selected dairy farms. Individual animals were selected using simple random sampling method from dairy farms. The presence of mastitis was determined based on clinical manifestation for clinical positive and indirect test (CMT) for sub clinical mastitis. Age, parity, lactation stage, breed and hygienic milking were considered as risk factors in our study. Age of the cows was determined by observing their dentition characteristics and grouped into < 5years, 5- 7years and > 8years categories. Parity was categorized into 1-3 calves, 4-6 calves and $>6$ calves. Milking hygiene practice was grouped into good (if there is a practice of washing and drying udder with separate towels, milking healthy and young cows first) and poor (if washing and drying of udder with a separate towel and milking with order is not practiced). Lactation stage of the cow was also categorized into early stage lactation (1-3 months), mid lactation (4-6 months) and late lactation (above 7 months). Physical visualization and manual palpation of udder and teat were used to examine clinically the udders. The presence of inflammation of udder (heat, pain, redness, swelling, loss of function) considered as clinical mastitis.

Milk samples were collected from individual quarters of apparently healthy lactating cows according to the procedures recommended by National Mastitis Council, [13]. The washing should be started sufficiently in advance of milking to allow the udders to drain dry before collection of the samples. After the udders, especially teats were cleaned and dried; the first 3-4 streams of milk were discarded. California mastitis test was carried out according to the method described by [14]. After withdrawing of the first two or three streams of milk about $2 \mathrm{ml}$ of the foremilk was collected from each quarter and mixed thoroughly in a plastic container. Two $\mathrm{ml}$ of composite milk was placed in a cup if the paddle to which an equal amount of CMT reagent was added. Then, the paddle was rotated gently in a circular pattern for 10 seconds so that the milk and reagent mixed well. Immediately the reactions were scored and the paddle was rinsed and shaken of excess moisture, The CMT reactions were scored and interpreted according to [15]. Both 0 (negative) and $\mathrm{T}$ (Trace) scored and interpreted absence of intra mammary infection, while CMT scores 1, 2 and 3 was considered as positive indicators of the infection [16].

\section{Data Management and Analysis}

The data were entered and managed in Microsoft Excel. All the data analysis was done by Statistical Package for Social Science (SPSS) software version 20. Descriptive statics such as percentages and frequency distribution were used to describe the nature and the characteristics of data.

\section{Results}

A total of 384 lactating cows (51 local, 214 exotic and 119 cross breeds) those were examined, $116(30.2 . \%)$ and $25(.6 .5 \%)$ were found to be positive subclinical and clinical examination, respectively. Therefore, the overall prevalence of bovine mastitis was found to be $36.7 \%$ at cow level. From the total of 1536 quarters examined, $15(0.97 \%)$ of them were found blind and nonfunctional. The remaining quarters 1521 (99.02\%) were functional; and out which $28(1.82 \%)$ quarters were clinically affected by mastitis and $243(15.82 \%)$ quarters were affected by sub- clinical mastitis (Table 1). California Mastitis Test (CMT) result found that $1(0.26 \%)$, $39(10.15 \%)$, and 101(26.30\%) in local, cross, and exotic breeds, respectively. The prevalence of bovine mastitis in relation to age indicated that $82(21.35 \%), 14(3.64 \%)$ and $50(13.02 \%)$ in $>8,5-7$ and 3-5 age of lactation cows respectively; and it was found that the association of bovine mastitis in relation to Age indicated that $82(21.35 \%), 14(3.64 \%)$ and $50(13.02 \%)$ in $>8,5-7$ and $3-5$ age of lactation cows respectively; and it was found that the association of bovine mastitis in relation to age of lactation was highly statistically significant $(\mathrm{P}<0.05)$. The prevalence of bovine mastitis in relation to parity was different, with different parity of cows and it was 29(7.55\%),69(17.96\%) and 43(11.19\%) in 1- 3 parity: $3-6$ parity and greater than 6 parity, respectively. In regard to lactation stage the finding indicted that 25(6.51\%), 53(13.80\%) and 63(16.40\%) in early, mid, and late lactating cows respectively (Table 2). The association of the prevalence of bovine mastitis with different risk factors was assessed; and different factors were considered as potential risk factors for bovine mastitis.

Table 1: Prevalence of mastitis at cow and quarter level of some dairy farms in and around Debra Tsige town.

\begin{tabular}{|c|c|c|c|}
\hline Tested Teat & $\begin{array}{c}\text { Number } \\
\text { animals and } \\
\text { quarter tested }\end{array}$ & $\begin{array}{c}\text { Number } \\
\text { Positive }\end{array}$ & $\begin{array}{c}\text { Prevalence } \\
\text { (\%) }\end{array}$ \\
\hline Clinical mastitis & 384 & 25 & 6.50 \\
\hline Cow level & 1536 & 28 & 1.82 \\
\hline $\begin{array}{c}\text { Quarter level } \\
\text { (functional teat) }\end{array}$ & 1536 & 15 & 0.97 \\
\hline $\begin{array}{c}\text { Non-function } \\
\text { (Blind) teat }\end{array}$ & 384 & 116 & 30.20 \\
\hline $\begin{array}{c}\text { Sub - clinical } \\
\text { mastitis }\end{array}$ & 1536 & 243 & 15.82 \\
\hline Cow level & 1536 & 271 & 17.64 \\
\hline Quarter level & 1536 & 15 & 0.97 \\
\hline Overall prevalence & & & 36.70 \\
\hline Cow level & 384 & 141 & \\
\hline Quarter level & 1536 & & \\
\hline Blind & & & \\
\hline
\end{tabular}


Table 2: Association of the prevalence of bovine mastitis with different breeds of dairy cows.

\begin{tabular}{|c|c|c|c|c|c|c|}
\hline Risk factors & Category & $\begin{array}{l}\text { No. of cows } \\
\text { examined }\end{array}$ & $\begin{array}{l}\text { No. of cows } \\
\text { affected }\end{array}$ & Prevalence (\%) & $\mathbf{X}^{2}$ & P-value \\
\hline \multirow{4}{*}{ Origin } & Wakene & 96 & 29 & 7.55 & \multirow{4}{*}{13.11} & \multirow{4}{*}{0.041} \\
\hline & D/Tsige & 96 & 44 & 11.45 & & \\
\hline & G/Wartu & 96 & 38 & 9.89 & & \\
\hline & D/Jibbo & 96 & 30 & 7.81 & & \\
\hline \multirow{3}{*}{ Age } & $>8$ & 27 & 82 & 21.35 & \multirow{3}{*}{4.5} & \multirow{3}{*}{0.34} \\
\hline & $5-8$ & 186 & 14 & 3.64 & & \\
\hline & $3-5$ & 171 & 50 & 13.02 & & \\
\hline \multirow{3}{*}{ Breed } & Cross & 119 & 39 & 10.15 & \multirow{3}{*}{39.06} & \multirow{3}{*}{0.00} \\
\hline & Local & 51 & 1 & 0.26 & & \\
\hline & Exotic & 214 & 101 & 26.30 & & \\
\hline \multirow{3}{*}{ Parity level } & $1-3$ & 172 & 29 & 7.55 & \multirow{3}{*}{67.83} & \multirow{3}{*}{0.00} \\
\hline & $4-6$ & 150 & 69 & 17.96 & & \\
\hline & $>6$ & 62 & 43 & 11.19 & & \\
\hline \multirow{3}{*}{ Lactation stage } & Early & 157 & 25 & 6.51 & \multirow{3}{*}{61.09} & \multirow{3}{*}{0.00} \\
\hline & Mid & 116 & 53 & 13.80 & & \\
\hline & Late & 111 & 63 & 16.40 & & \\
\hline
\end{tabular}

\section{Discussion}

Mastitis is an economically important disease of dairy cattle worldwide causing a significant reduction in milk yield and sometimes posing public health hazard. In the present study, a total of 384 cows ( 51 local zebu, 214exotic and 119 cross breeds) from small holder, medium and large sized dairy farms were investigated to determine the prevalence of clinical and sub-clinical mastitis and associated risk factors. One hundred fourth one (36.7\%) of the examined animals had abnormalities in their udder, teats, and milk as evidence of mastitis. This finding was lower than finding from many previous studies conducted [18-23] who had reported a prevalence of bovine mastitis 53.0\%, 53.30\%, 52.20\% and $48.6 \%$ respectively of the overall prevalence of bovine mastitis in different part of Ethiopia. This difference may be due to difference in the intrinsic factors such as the breed of animals examined and extrinsic risk factors prevailing in the environment of animals or in the immediate production conditions on the farms, the abnormalities in the udders and the sampling techniques and test method used in the studies.

Prevalence of subclinical mastitis (30.2\%) is higher than that of clinical mastitis (6.5\%)in the present study which is in the agreement with several earlier reports from different parts of Ethiopia [24-30] and elsewhere in Africa [31]. Since, environmental factors play significant role, the prevalence of subclinical mastitis varies in dairy farms [32-35]. Additional agreement to other reports; clinical mastitis is far lower than subclinical mastitis [3640]. This could be attributed to little attention given to subclinical mastitis, as the infected animal shows no obvious symptoms and secrets apparently normal milk and farmers, especially small holders, are not well informed about invisible loss from subclinical mastitis. In Ethiopia, the subclinical forms of mastitis received little attention and efforts have been concentrated on the treatment of clinical cases [41]. In current finding, sub- clinical and clinical mastitis at cow level was found to be $36.7 \%$ which in line with the result reported who had reported $31.7 \%, 34.3 \%, 34.4 \%$, respectively. Additionally, the present result (36.7\%) agrees with the finding of Mungube, and Tadesse who had reported $46.6 \%$ and $43.4 \%$ respectively.

This difference might be due to diagnosis techniques. Quarter prevalence of mastitis $17.18 \%$ found in this study was lower than the finding of Umer [42] in Pakistan, who reported the 34.5\%, $37 \%, 28.2 \%$ and $35.25 \%$, by quarter prevalence. The occurrence of bovine mastitis and lactation stage was higher in cows in late lactation stage followed by early and medium lactation stages that are not in agreement with previous reports. The late lactation stage infection might be due to the contamination of cow teat during milk period. On other hand, absence of dry cow therapy regime could possibly be the major factor contributing to high prevalence at early lactation and early infection associated with delayed diapedesis of neutrophils into the mammary gland. Additionally it was found that the association of bovine mastitis in relation to stage of lactation was statistically significant difference. That means late lactation period was more likely affected than early lactation period. On other side the result was found that the association of bovine mastitis in relation to parity had statistically significant $(\mathrm{P}<0.05)$.

This study as well as other similar studies showed that the overwhelming cases of mastitis were sub-clinical as compared to that of clinical mastitis among the three breeds. This because subclinical form of mastitis receives a little attention in our country and efforts have been concentrated on the treatment of 
clinical cases, while the high economic loss could come from sub clinical mastitis. So that considerable number of Ethiopia farmers especially smallholders must be informed about the invisible loss from subclinical mastitis. In our study the association of bovine mastitis with different host risk factors was assessed. Among the host potential risk factors presumed to have significant association with bovine mastitis were age, breed, and parity and lactation stage. The finding of this study indicated that high prevalence was recorded in parity of greater than 6 parity $11.19 \%$ followed by 1-3 (7.55\%) and 4-6 parity (17.96\%). The findings those were obtained in this study agreed with previous findings of Lamma and Tibeb. Their studies showed that older cows especially after 4 calves were more susceptible to bovine mastitis than the others; exotic breeds were more susceptible than others. Similar results are showed by Richard.

\section{Conclusion}

Mastitis especially subclinical mastitis is a problem, which threatens dairy farm owners usually by decreasing milk yield irrespective of adequate feed provision and deworming practices. Farmers are only concerned with clinical mastitis and often are unaware of the status of sub-clinical infection in their herds and no visible control strategies of mastitis are currently in most dairy farms. The present study showed that an overall prevalence of $36.7 . \%$ bovine mastitis was recorded in the study area. The prevalence of subclinical mastitis (30.2\%) is higher than that of clinical mastitis (6.5\%). Several risk factors such as breed, parity number, and lactation stage, and also environmental sanitation were found to be associated with mastitis, indicating the potential opportunities for improved management conditions of the farms and the subsequent economic returns that can be obtained with the reduced losses.

\section{Acknowledgement}

The author acknowledges the almighty God, Wollega University and Debra Libanos Wereda Livestock and Fishery office.

\section{References}

1. Abera M, Demie B, Aragaw K, Regassa, F, Regassa, A (2010) A Isolation and identification of Staphylococcus aure us from bovine mastitis milk and their drug resistance patterns in Adamstown, Ethiopia. Journal of Veterinary Medicine and Animal Health 2(3): 29-34.

2. Adama town. DVM Thesis, FVM, AAU, Debra Zeit, Ethiopia.

3. Alemayehu M (2003) Country Pasture/Forage Resource Profiles. In Suttie JM, Reynolds SG (Eds.), p. 1-36.

4. Andrews AH, Blowey RW (2004) Bovine Diseases, Medicine and Husbandry of Cattle. In Andrews AH, Blowey RW (Eds.), (2 $2^{\text {nd }}$ edn.). Black well Science Ltd, UK pp: 326-360.

5. Awale MM, Dudhatra GB, Avinash Kumar, Chauhan BN, Kamani DR (2012) Bovine mastitis: A threat to the economy. Open Access Reports. Online 1: 295.

6. Bachaya, HA Raza MA, MurtazaS, Akbar IU R (2011) Subclinical bovine mastitis in Muzaffar Garhdistrict of Punjab (Pakistan).Australian Agricultural consulting and Management Company, Adelaide, Australia. PP: 111. The Journal Animal and Plant Science 21(1): 16-19.
7. Berhanu S (1997) Bovine mastitis in dairy farms in Dire Dawa administration Council and eastern Hararge Zone. Prevalence, isolation and "in vitro" antimicrobial susceptibility studies. DVM thesis, FVM, AAU, Debra Zeit, Ethiopia.

8. Biffa D, Debela E, Beyene F (2005) Prevalence and risk factors of mastitis in lactating dairy cowsin southern Ethiopia. International Journal of Application Research in Veterinary Medicine. 3: 189-198

9. Bishi AS (1998) Cross sectional and longitudinal prospective study of bovine mastitis in urban and peri-urban dairy production system in the Addis Ababa region, Ethiopia. MSc Thesis, FVM, School of graduate studies, Freie University, Berlin, DWLFO, 2014: Debretsige Woreda Livestock and Fishery Office

10. Suttie JM, Reynolds SG (2003) FAO-STAT. FAO Statistics Database on the World Wide Web. In Suttie JM, Reynolds SG (Eds.), pp. 1-36.

11. Gera S, Guha A (2011) Assessment of acute phase proteins and nitric oxide as indicator of subclinical mastitis in Holstein Haryana cattle. Indian Journal of Animal Sciences 81(10): 1029-1031.

12. Getahun K, Belihu K, Bekana M, Lobago F (2008) Bovine mastitis and antibiotics resistance pattern in Selalle smallholder dairy farms, Central Ethiopia. Tropical Animal Health Production 40(4): 261-268.

13. Gizat AE (2004) A cross sectional study of bovine mastitis in and around Bahir Dar and Antibiotic resistance patterns from major pathogens. MSc thesis, FVM, AAU, Debrezeit, Ethiopia

14. Haftu R, Taddele H, Gugsa G, Kelayou S (2012) Prevalence, bacterial causes, and antimicrobial susceptibility profile of mastitis isolates from cows in large-scale dairy farms of Northern Ethiopia. Tropical Animal Health Production 44(7): 1765-1771.

15. Hussein N (1999) Cross sectional and longitudinal study of bovine mastitis in urban and peri urban dairy system in the Addis Ababa Region, Ethiopia. MSc Thesis, FVM, AAU, School of Graduate studies and Freie University, Berlin.

16. Hussein N, Yehualashet T, Tilahun G (1997) Prevalence of mastitis in different local and exotic breeds of milking cows. Est Agr Sci 16: 53-60.

17. Jimmy LH (1995) Mastitis current veterinary therapy. In: Food Animal practice London, WB Saunders Co, Philadelphia ( $3^{\text {rd }}$ edn.). Pp: 943-963.

18. Kass T, Wirtu G, Tegegne A (1999) Survey of mastitis in dairy herds in the Ethiopian Central Highlands. Ethio J Sci 22: 291-301.

19. Kerro 0, Tareke F (2003) Bovine Mastitis in selected areas of Southern Ethiopia. Trop. Anim Hath Prod 35(3): 197-205.

20. Lakew M, Tolosa T, Tigre W (2009) Prevalence and major bacterial causes of bovine mastitis in Asella, South Eastern Ethiopia. Tropical Animal Health Production 41(7): 1525-1530.

21. Lamma D (2005) Study on bovine mastitis in small holder dairy farm, in Degem District, Central Ethiopia. DVM Thesis, FVM, AAU, Debra Zeit, Ethiopia 13(1): 23-32.

22. Lemma M, Kassa T, Tegegne A (2001) Clinical manifested major health Problems of Cross breed dairy herds in the central highlands of Ethiopia. Trop Anim Hath Pro 33(2): 85-89.

23. Mekibib B, Furgasa M, Abunna F, Megersa B, Regassa A (2010) Bovine Mastitis, Prevalence, Risk Factors and Major Pathogens in Dairy Farms of Holeta town. Central Ethiopia. Veterinary World 3(9): 397-403.

24. Mungube ED, Tenhagen BA, Kassa T, Regessa F, Kyule MN (2004) Risk factors for dairy cows in the central highland of Ethiopia. Tropical Animal Health and Production 36(5): 463-472.

25. Mungube EO (2001) Management and economics of dairy cow mastitis in the urban and peri urban areas of Addis Ababa. MSc Thesis, FVM, AAU, Debra Zeit, Ethiopia.

26. Musse T (2010) A study on the occurrence of bovine mastitis in veterinary clinic at Addis Ababa and its surrounding. DVM Thesis, School Veterinary Medicine, AAU, Debra Zeit, Ethiopia. 7(2): 40-48. 
27. Nessru H, Teshome Y, Getachew T (1997) Prevalence of mastitis in crossbred and zebu cattle. Ethiopian Journal of Agricultural Science 16: 53.

28. NMC (1990) Microbiological procedures for the diagnosis of bovine udder infection. ( $3^{\text {rd }}$ edn.) Arlington VA: National Mastitis Council Inc.

29. Quinn PJ, Carter ME Markey B, Cater GR (1999) California Mastitis Test (CMT) In clinical veterinary microbiology. ( $1^{\text {st }}$ edn), Wolfe Publishing, London pp: 333-334.

30. Radostits OM, Gay CC, Hinch Kliff KW, Constable PD (2007) Mastitis in Veterinary medicine. In Radostits OM, Gay CC, Hinch Kliff KW, Constable PD (Eds.), (10 ${ }^{\text {th }}$ edn.), Elsevier, Nether Lands.

31. Radostits OM, Gay CC, Blood DC, Hinch kliff KW (2000) Veterinary Medicine: A Textbook of the Diseases of Cattle, Sheep, Pigs, Goats and Horses. In Radostits OM, Gay CC, Blood DC, Hinch kliff KW (Eds.), (9 ${ }^{\text {th }}$ edn.), ELBS Baillier Tindall See pp: 563-660.

32. Richard R (1993) Dairying in the tropical agriculturalist. In Richard R (Eds.), (1 ${ }^{\text {st }}$ edn.), Macmillan press London. pp: 43-48.

33. Schalm OW, Carrlole EJ, Jain NC (1971) Bovine Mastitis. Philadelphia Lea and Fibiger. USA. Pp 1-21.

34. Sharma H, SK Maiti, Sharma KK (2007) Prevalence, etiology and antibiogram of microorganisms associated with sub-clinical mastitis in buffaloes in Drug Chhattisgarh state. Int J Dairy Sci 2(2): 145-151.

35. Sharma N (2010) Economically important production diseases of dairy animals. In Sharma N (Eds.), (1 $1^{\text {st }}$ edn.), Sarva Manav Vikash Samiti,

ISSN: 2574-1241

DOI: $10.26717 /$ BJSTR.2020.28.004619

Debela Abdeta. Biomed J Sci \& Tech Res

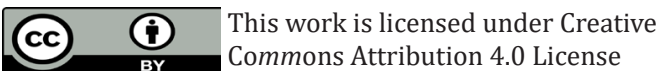

Submission Link: https://biomedres.us/submit-manuscript.php
Gurgoan, India pp. 47-65.

36. Sori H, Zerihun A, Abdicho S (2005) Dairy Cattle Mastitis in Sebeta, Ethiopia. International Journal of Veterinary Medicine 3: 332-338.

37. Takele S (1987) A study of incidence of bovine mastitis in different cooperative dairy farms in Chilalo Awrajas, Arsi region. DVM Thesis, FVM, AAU, Debra Zeit, Ethiopia

38. Tesfaye H (1995) Prevalence of bovine mastitis in indigenous Zebu and Boran Holstein Cross in South Wollo, isolation and drug sensitivity of isolates. DVM Thesis, FVM, AAU, Debra Zeit, Ethiopia.

39. Thrus field M (2005) Veterinary epidemiology. In: Thrus field M (Eds.), ( $3^{\text {rd }}$ edn.), Black well publishing, UK, p. 339.

40. Tibeb Silassie S (2003) Studies on the prevalence, isolation of dominant bacteria and their susceptibility to antibiotics at Muka - Turri town, Central Ethiopia. DVM Thesis, FVM, AAU, Debra Zeit, Ethiopia.

41. Umer Seid, Tilahun Zenebe, Gizat Almaw, Abdela Edao, Haimanot Disassa (2015) Prevalence, Risk Factors and Major Bacterial Causes of Bovine Mastitis in West Arsi Zone of Oromia Region, Southern Ethiopia

42. Workineh S, Bayleyegne M, Mekonnen H, D Potgieter LND (2002) Prevalence and Etiology of mastitis in cow from two major Ethiopian dairies. Trop Anim Hlth production 34(1): 19-25.

43. Yalcin C (2000) Cost of mastitis in Scottish dairy herds with low and high sub-clinical mastitis problems. Turk J Vet Anim Sci 24: 465-472.

$\begin{array}{ll}\text { BIOMEDICAL } & \text { Assets of Publishing with us } \\ \text { RESEARCHES } & \text { - Global archiving of articles } \\ \text { - Immediate, unrestricted online access } & \text { - Rigorous Peer Review Process } \\ & \text { - Authors Retain Copyrights } \\ \end{array}$

